
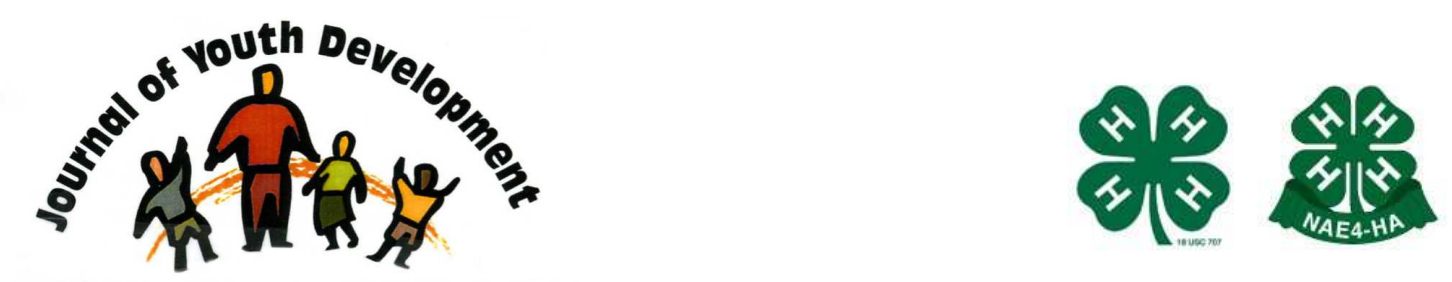

Bridging Research \& Practice

\title{
The Impact of a Youth Development Program on Secondary Students' Career Aspirations
}

\author{
Bonita Williams \\ Department of Human Development, Faculty Affiliate \\ Virginia Polytechnic Institute and State University \\ Blacksburg, VA \\ bonita.williams@vt.edu \\ Jody Thompson \\ Multicultural Academic Opportunities Program \\ Virginia Polytechnic Institute and State University \\ Blacksburg, VA \\ jodyt@vt.edu \\ Tonya Taylor \\ Virginia Cooperative Extension \\ Virginia Polytechnic Institute and State University \\ Blacksburg, VA \\ totaylor@vt.edu \\ Karen Eley Sanders \\ Academic Enrichment \& Excellence \\ Virginia Polytechnic Institute and State University \\ Blacksburg, VA \\ kesanders@vt.edu
}




\title{
JOURNAL OF YOUTH DEVELOPMENT \\ bridging research and practice

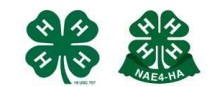

Volume 5, Number 3, Fall 2010

Article 100503FA006

\section{The Impact of a Youth Development Program on Secondary Students' Career Aspirations}

Bonita Williams, Jody Thompson, Tonya Taylor and Karen Eley Sanders Virginia Polytechnic Institute and State University

\begin{abstract}
This study's purpose determined the extent to which adolescents' participation in a youth development program may be linked to the participants' post-secondary education and career aspirations. One hundred and seven adolescents, ages 14-19 in grades 8-12 completed Holland's Vocational Interest Survey and the 4-H Career Decision Survey. Ordinal regression analysis indicated participation in 4-H had a positive impact on career decisions for students who participated in $4-\mathrm{H}$ for two years $(\mathrm{p}<.038)$ and six years $(\mathrm{p}<.001)$. Significant differences were apparent with $80 \%$ of the racial/ethnic groups surveyed concerning a college fair's impact on career choice and college major determination.
\end{abstract}

\section{Introduction}

Youth have numerous opportunities to explore careers during their preteen and adolescent years. According to Verhoeve (2003), youth have a cursory knowledge of approximately 50 occupations. They gain this knowledge through television, electronic media, neighbors, family and friends. Youth have good knowledge of approximately 12 occupations and an excellent knowledge of approximately six. As youth age, they have increased opportunities to gain detailed information concerning careers. Some of those opportunities include career fairs, job shadowing, and participating in youth development programs such as 4-H (Michigan State University Extension, 2009).

Currently one of the foremost youth development initiatives in the United States (NIFA, 2009), 4-H has its origins in the Land-Grant University. The Land-Grant University has four subjectmatter areas of support: Agriculture, Family and Consumer Science, Community Viability, and 4-H and Youth Development. Helping youth develop leadership and other life skills is one of the main emphases of the 4-H Youth Development program (Hendricks, 1996). The 4-H Youth Development program believes in providing settings where youth can learn experientially "through hands-on interaction with the subject matter" (Arnold, 2003, Introduction section, 
para. 2). The interaction is accomplished through participation in one of the 13 4-H delivery modes; among them are 4-H clubs, camps, special interest programs, and school enrichment (Garst, Hunnings, Jamison, Hairston, Meadows, \& Herdsman, 2006).

The Virginia Cooperative Extension 4-H Youth Development Program, in collaboration with the Center for Academic Enrichment and Excellence implemented a career/college fair in conjunction with the annual 4-H Congress in 2008. State 4-H Congress is an annual conference of youth who participate in 4- $\mathrm{H}$. The purpose of 4- $\mathrm{H}$ Congress is to provide education and lifeskill development for participants. Students not only participate in workshops, but also compete in statewide competitions in 10 curriculum areas (Virginia Cooperative Extension, n.d.).

The career/college fair was developed to expose the 4-H'ers to career and post-secondary education options. The college fair also provided an opportunity for 4-H'ers as prospective post-secondary students to receive specific information regarding college and universities, including entrance requirements, academic degree programs and funding options.

Thirty-three higher education institutions from around the Commonwealth participated in the fair. Eight college departmental representatives from Virginia Polytechnic Institute and State University provided information about their programs of study and the occupations youth might consider. This study sought to determine the impact of the career/college fair on the participants and specifically addressed two broad research questions:

1.) Do participants' career aspirations vary by race/ethnicity, curricula participation, and years of participation in a youth development program?

2.) Does participation in a youth development program help to clarify participants' career aspirations?

\section{Review of Literature}

This study sought to determine the extent to which adolescent participation in a youth development program may be linked to the participants' post-secondary education and career aspirations. Factors that were of particular interest included age, race/ethnicity, curricula participation, and years of participation in the program. This section will present literature that highlights the theoretical framework of the study, as well as a review of studies that offer a descriptive analysis of college choice and career aspirations by select demographic characteristics.

\section{Theories in Career Development}

A number of theories have been developed to explain career development, more recently, theories of vocational psychology and career development that have substantive relevance are Holland's Career Typology (1997), the Theory of Circumscription (Gottfredson, 1981), the Social Learning Approach to Career and Decision Making (Mitchell \& Krumboltz, 1996), and Social Cognitive Career Theory (Lent, Brown, \& Hackett, 1994). Two noted and relevant theories by Super (1954) and Holland (1959, 1997), serve as the foundation for the current study. Super's theory (1954) has six life and career developmental stages which have been coined as the Life Span Vocational Choice Theory (Salomone, 1996). The six stages include:

a) crystallization/exploratory stage (ages 14-18),

b) specification stage (ages 18-21), 

c) implementation stage (ages 21-24),
d) stabilization stage (ages 24-35),
e) consolidation (age 35), and
f) readiness for retirement (age 55).

The life span vocational choice stresses the importance of self-concept and the work world demands adaptation of their career choice.

The crystallization/exploratory phase is indicative of the time in an adolescent's life when they begin to define their identity as an adult through social and career choices (Duffy \& Blustein, 2005). During this stage, youth narrow their choices, although they are not firm (Patton \& McMahon, 1999). Adolescents' career choice is influenced by the community resources available to them, support by family members (Jackson, Kacanski, Rust \& Beck, 2006), and the selfefficacy of the adolescents (Anderson \& Brown, 1997).

The purpose of Holland's $(1959,1997)$ theory was to match an individual's personality type with a similar work environment. After years of research examining vocational choice, Holland concluded that there were six individual personality types in which individuals were categorized: Artistic, Enterprising, Investigative, Realistic, Conventional, and Social. Depending on the personality, people generally prefer to work in environments that are dominated by personalities similar to their own.

\section{Career Preparation, Gender, and Socioeconomic Status}

Important career decisions, such as whether to attend college, a technical school, enter the military, or go directly into the job market after high school are made during adolescence (Adams, Benshoff, \& Harrington, 2007; Turner \& Lapan, 2002). The students' environments can have an impact on their career aspirations after high school. The earliest influences on students are their parents and other adults in their lives, such as teachers, program directors, and mentors. Having support from parents or other adults helps students to develop career goals for themselves (Ali \& Saunders, 2006; Anderson \& Brown, 1997). When students have lower aspirations about their life after high school, they tend to have low grades in school and have lower aspirations regarding their future career (Jackson, Kacanski, Rust, \& Beck, 2006).

Other researchers (Carter, Thompson \& Warren, 2004; Childs \& McKay, 2001; La Londe, Leedy \& Runk, 2003; Rollins, 2003; Tournaki, 2003) have investigated the effects of students' gender and socio-economic status on teachers' perceptions of academic success. Teachers tend to predict greater social and academic success for females than males; teachers who do not teach math were more likely to agree that success in math is more of a male attribute (Carter et al., 2004). Furthermore, students from low socio-economic backgrounds were perceived as having less potential in math and language arts than other students.

Cicourel and Kitsuse (1963) and Tomini and Page (1992) interviewed counselors and teachers regarding class (or student) placement decisions of the students they served. Those interviewed claimed that their decisions were based on objective measures (such as exam scores). Yet, these researchers found that social class was an important influence in the decision. Students who had similar academic and conduct records but who came from a lower social class were often classified by these same educators as being less likely to succeed in college and more apt for less academically rigorous options such as on-the-job training and the military. Thus, the 
researchers concluded that the subconscious perception of these educators' was the higher one's socioeconomic status the more successful they would be when the academic rigor of the job increased.

Sadly, both teachers and counselors had a tendency to stereotype students based on small amounts of information (e.g. gender and socio-economic status) (Jackson \& Nutini, 2002). Therefore, teachers and counselors must be able to recognize their own stereotypes and put those biases aside. Doing so will allow teachers and counselors to be instrumental in reducing educational inequalities due to gender and socio-economic status thus opening up opportunities and facilitating vocational training and college entry for all, regardless of gender or social class.

The purpose of this study was to determine if career aspirations of youth varied by age, race/ethnicity, curricula exposure, and years of participation in a non-formal youth development program. Appropriate methodologies examined the study questions.

\section{Methodology}

Data were collected using the 4-H Career Decision Survey (Williams \& Taylor, 2008) designed by Virginia 4-H Specialists and administered during the first career/college fair coordinated by the Virginia Tech Academic Support Services. The survey was administered during the 2008 Virginia State 4-H Congress. The fair was a collaboration between the Virginia 4-H Youth Development Program and CAEE.

Before attending the career/college fair, 4-H youth were given a modified version of the Holland's Vocational Preference Inventory (VPI, 1985). The VPI was suitable for high school students; it was designed for youth to determine their possible career interests. The VPI served as a companion instrument to assist youth in discovery of possible career areas to consider. Included with the instrument was a description of the typologies (Realistic, Enterprising, Artistic, Investigative, Social and Conventional), careers students might consider, skills associated with each typology, and college majors students might consider. For the 1985 version of the inventory, the following psychometric properties were reported. Holland (1985) reported mean values ranging from 1.39 (Realistic Scale) to 4.32 (Social Scale) for a sample of female 9th through 12th grade high school students. A sample indicated mean values ranging from .91 (Realistic Scale) to 3.05 (Social Scale). Test-retest reliability coefficients for the VPI have varied between .80 and .54 depending upon the high school sample (Holland, 1985; Meinster \& Rose, 2001).

\section{Participants}

The VPI (1985), approved by the Virginia Tech Human Subjects Institutional Review Board, was offered to 298 youth ages 14-19 who had the option to attend the career/college fair. One hundred and seven youth submitted a completed survey with $72 \%$ of the respondents being female and $28 \%$ being male. The racial/ethnic groups that completed the survey were follows: African-American (29.9\%), Asian (0.9\%), Bi or Multiracial $(1.9 \%)$, Caucasian $(58.9 \%)$, Latino/Hispanic (4.7\%), and Other (3.7\%). This was a sample of convenience.

\section{Instrument}

For this study, authors Williams and Taylor (2008) developed the 4-H Career Decision Survey. The 4-H Career Decision Survey was designed to measure the influence that 4-H Youth Development and the 2008 career/college fair had on the career aspirations of $4-\mathrm{H}$ youth. The 
survey took less than 10 minutes to complete. The 4-H Career Decision sample survey included 10 items measuring dependent variables; some sample items are listed:

1) "4-H has helped me in my college major choice;"

2) "My 4-H club experiences have helped me decide a college major;"

3) "Participating in this college fair gave me a better understanding of what I would like my college major to be;" and,

4) "The Career Interest Inventory was helpful in determining my career interests."

The Career Decision survey served also as a background questionnaire to collect pertinent demographic information. Because of the small sample size, validity and reliability were not tested.

The 4-H Career Decision Survey consisted of the following variables: seven dependent variables and six independent variables. The six independent variables were gender, district, number of years in 4-H, race/ethnicity, and major/favorite project. The response categories were ordinal: "strongly agree," "agree," "no response," "disagree," and "strongly disagree." The survey used a five item Likert scale ranging from five (strongly agree) to one (strongly disagree).

The analysis employed ordered logit regression to conduct the multivariate analysis. The ordinal regression method of analysis appears to measure the effects of multiple explanatory variables that were not assumed continuous and is appropriate for data that is evenly distributed among all categories. This ordinal regression technique allows modeling of dependence of an ordinal or ordered response on a set of predictor covariates (Hummel \& Lichtenberg, 2001; Thomas \& Galamos, 2002).

\section{Results}

This section provides information on the significant positive relationships. Table 1 reports the estimates of ordinal regression and the results of the significance tests. The table discloses positive significance that deals with years in 4-H, age, race/ethnicity and specific 4-H projects. The results indicated that youth who participated in the 4- $\mathrm{H}$ animal science project had knowledge about various careers before completing the modified Holland's Inventory (.038 $\leq$ .05); results also indicate that other experiences outside of $4-\mathrm{H}$ had a significant impact on animal science project students learning about careers (.025 $\leq .05)$. 4-H had a significant impact on career aspirations of youth who participated in $4-\mathrm{H}$ for two years $(.038 \leq .05)$ and six years $(.001 \leq .05)$; for youth who participated in $4-\mathrm{H}$ for seven years, experiences outside of $4-\mathrm{H}$ assisted them with exploring careers $(.042 \leq .05)$. For students participating in the $4-\mathrm{H}$ camping program, experiences outside of $4-\mathrm{H}$ were significant in career exploration $(.05 \leq .05)$ (see Table 1). 
Table 1

Ordinal Regression on 4-H Youths' Career Decisions (Estimates) $(n=107)$

\begin{tabular}{|c|c|c|c|c|c|c|}
\hline VARIABLES & $\begin{array}{c}\text { Knowledge } \\
\text { of } \\
\text { Interests } \\
\text { Before } \\
\text { Career } \\
\text { Interest } \\
\text { Inventory } \\
\end{array}$ & $\begin{array}{c}\text { 4-H } \\
\text { Experiences } \\
\text { and Career } \\
\text { Choice }\end{array}$ & $\begin{array}{c}\text { Other } \\
\text { Experiences } \\
\text { and Career } \\
\text { Choice }\end{array}$ & $\begin{array}{c}\text { Career } \\
\text { Interest } \\
\text { Inventory } \\
\text { and } \\
\text { Career } \\
\text { Interests }\end{array}$ & $\begin{array}{c}\text { College Fair } \\
\text { and College } \\
\text { Major } \\
\text { Determination }\end{array}$ & $\begin{array}{l}\text { College } \\
\text { Fair } \\
\text { and } \\
\text { Career } \\
\text { Choice }\end{array}$ \\
\hline \multicolumn{7}{|l|}{ YEARS IN 4-H } \\
\hline 2 Years & .659 & $.038 *$ & .591 & .275 & .883 & .632 \\
\hline 6 Years & .531 & $.001 *$ & .349 & .921 & .394 & .571 \\
\hline 7 Years & .998 & .421 & $.042 *$ & .669 & .499 & .998 \\
\hline \multicolumn{7}{|c|}{ RACE/ETHNICITY } \\
\hline African Am./Black & .111 & .783 & .067 & $.045^{*}$ & $.000 *$ & $.002 *$ \\
\hline Asian/Pacific Is. & .400 & .559 & .079 & .172 & $.000 *$ & $.002 *$ \\
\hline Caucasian/White & .997 & .808 & .770 & .291 & $.004 *$ & Oa \\
\hline Latino/Hispanic & .572 & .262 & .056 & .140 & $.018^{*}$ & $.042 *$ \\
\hline \multicolumn{7}{|l|}{ 4-H PROJECT } \\
\hline Animal Science & $.038 *$ & $.025^{*}$ & .151 & .604 & .121 & .181 \\
\hline Camp/Outd. Ed. & .155 & .850 & $.050 *$ & .189 & .454 & $.021 *$ \\
\hline
\end{tabular}

${ }^{*}=p \leq .05$

The Holland Career Interest Inventory was significant in assisting African-American youth with understanding their career interests $(.045 \leq .05)$. The college fair helped to clarify college interests for the following racial categories: African-American/Black (.000 $\leq .05)$, Asian/Pacific Islander $(.000 \leq .05)$, Caucasian/White $(.004 \leq .05)$, and Latino/Hispanic $(.018 \leq .05)$. The racial/ethnic category that did not have significance was the bi-racial category.

The college fair showed indications of significance in assisting youth with understanding their career choice. Understanding career choice was significant with the following racial/ethnic categories: African-American/Black (.002 $\leq .05)$, Asian/Pacific Islander (.002 $\leq .05)$, and Latino/Hispanic (.042 $\leq .05)$.

Table 2 revealed model fit; goodness of fit was determined by model significance. A model does not fit well if the level of significance is less than or equal to .0005 (Norusis, 2008). The chi-square test was used to determine model goodness of fit (Moore \& McCabe, 1989). The model for this study fits well; all levels of significance on the dependent variables are greater than .0005 . 
Model fitness was supported by the following explanation of the significant dependent variables related to model fit. Levels of significance were revealed in relation to the dependent variables. 4-H Club Experiences (35.330) include primary educational mode of the 13 offered by the 4-H program. 4-H Experiences (39.083) are the general 4-H participation opportunities. Other Experiences (42.597) are activities besides 4-H that have an impact on youths' career decision or college major choice. 4-H Record Books (35.237) are the written curriculum that youth complete as a part of the 4- $\mathrm{H}$ non-formal education experience. College fair/Major (45.078) was the event that had significant impact on the youths' college major preference or choice. The college fair/career (40.936) was the dependent variable, which indicated a significant result regarding the youths' career choice. The one dependent variable that was not significant was the Interest Inventory (.081). The Career Interest Inventory (33.032) was administered to the youth to assist with identifying career interests (see Table 2).

Table 2

Model Fit for Dependent Variables and Goodness of Fit

\begin{tabular}{l|c|c|c|}
\hline Dependent Variables & Chi-Square & df & Sig. \\
\hline 4-H Club Experiences & 35.330 & 23 & $.048^{*}$ \\
\hline 4-H Experiences & 39.083 & 23 & $.019^{*}$ \\
\hline Other Experiences & 42.597 & 23 & $.008^{*}$ \\
\hline 4-H Record Books & 35.237 & 23 & $.049 *$ \\
\hline Interest Inventory & 33.032 & 23 & .081 \\
\hline $\begin{array}{l}\text { College fair/Major } \\
\text { College fair/Career }\end{array}<.05$ & 45.078 & 23 & $.004^{*}$ \\
\hline
\end{tabular}

A Pearson Chi square goodness of fit test determined large observed significant levels; this indicates models with good fit (Norusis, 2008). Large observed levels were indicated with the following dependent variables: 4-H Club Experiences (385.165), 4-H Experiences (290.028), Other Experiences (381.769), 4-H Record Book (282.028), college fair participation and College Major (282.310), and College Fair and Career Choice (313.025). The only variable without a large observed significance level was the Career Interest Inventory variable Career (582.588) (see Table 3). 
Table 3

Pearson Goodness of Fit Statistic for Dependent Variables

\begin{tabular}{|l|c|c|c|}
\hline Dependent Variables & Chi-Square & Df & Sig. \\
\hline 4-H Club Experiences & 385.165 & 377 & .377 \\
\hline 4-H Experiences & 290.574 & 377 & 1.00 \\
\hline Other Experiences & 381.769 & 377 & .422 \\
\hline 4-H Project Books & 282.028 & 377 & 1.00 \\
\hline Interest Inventory & 582.588 & 377 & .000 \\
\hline College Fair/Major & 282.310 & 377 & 1.00 \\
\hline College Fair/Career & 313.025 & 377 & .993 \\
\hline
\end{tabular}

\section{Limitations}

There were a few limitations to this study. First, over 500 students attended 2008 4- $\mathrm{H}$ Congress. However, due to youth's participation in statewide competitions conducted at the same time, not all students were able to attend the career/college fair. Second, the sample size for this study was too small for the results to be generalized to other 4-H youth programs outside of Virginia. Third, both instruments were piloted for the first time at this 4-H Congress and the validity and reliability for the instruments were not examined prior to their administration. Finally, the various 4-H clubs in Virginia learn about careers in a variety of ways. Some students did not complete a 4-H project. Since these projects expose students to different occupations, some students did not have $4-\mathrm{H}$ project-based career exposure.

\section{Discussion}

This study confirms that the 4-H experience does indeed have a significant impact on the career decisions of some youth, but not all. Specifically, youth who had participated in 4-H for two years, six years, and those who had participated in the animal science and outdoor education projects reported that 4-H was useful in helping them to decide on a career. This finding indicates that 4- $\mathrm{H}$ is exposing youth to specific careers and occupational experiences. The results of this study also demonstrate that students in 4-H have learned about careers not only by participating in $4-\mathrm{H}$, but with activities outside of $4-\mathrm{H}$. One can assume that students learn about careers not only in the schools that they attend, but also in the other developmental youth activities in which they participate. Many public schools in Virginia have career counselors who counsel students concerning future full-time employment and choice attendance.

However, when the student data were aggregated by race, the results indicated that the Career Interest Inventory, 4- $\mathrm{H}$ experiences and outside experiences were not helpful to any racial group in deciding career choice. This may be an indication that students had already decided on specific careers or that they are unsure about specific careers. However, Holland's Vocational Interest Survey was significant in assisting the African-American participants with understanding 
career interests. The students who participated in this study were between the ages of 14-19. Thus, they may not be ready or equipped to make decisions about their future careers. It would be useful for 4-H programs to intensify participants' exposure to various careers through 4-H projects. This would be developmentally appropriate for this age group.

The college fair was helpful to students in determining their possible academic major and career choice. Students were able to ask individuals about the classes concerning particular academic majors and future career choices. Talking to the representatives may have provided the student enough insight to decide whether to explore the major further and/or to think about other majors.

A future study for Virginia 4-H should focus on the types of outside organizations in which participants have membership. Researchers can examine whether these activities, including 4-H make a difference when students are deciding on careers.

\section{Implications}

Based on this study, the 4-H Youth Development Program may need to intensify its career awareness for youth ages 14-19. It is apparent that youth participants have become significantly aware of careers in Virginia through the animal science program and the outdoor education program in particular. Career awareness for this age group is developmentally appropriate as youth are seeking information regarding their next phase in life. This significant difference may address youth's departure from youth development programs that do not provide developmentally appropriate opportunities.

Long-term involvement in 4- $\mathrm{H}$ is evident in this study. Results of the research indicate that long-term participation in 4-H Youth Development has a positive impact on the career choice of youth. For instance, the 4-H community club programming and after-school programming are programs that assist with long-term youth development. These programs provide youth opportunities to experience mastery, belonging, generosity, and independence. In the club program or other long-term involvement opportunities involving a caring adult, the adult can create opportunities for youth to assess their experiences, service to others, and build in their successes for the future (Kress, 2004).

The college fair impacted eighty percent of the racial and ethnic groups in the study positively. Four-H youth development specialists and agents might consider efforts such as this to expose youth to career options in relation to their interests. The one group that did not show significant differences regarding participation in the career fair was those indicating bi-racial/multi-racial identity. This is consistent with other programming areas where needs of those of mixed racial identity are not being met (Root, 1996a; Root, 1996b). Specialists may look at this specific group to determine how to meet their needs regarding career awareness and decision-making.

\section{Summary}

This study's purpose was to determine the extent to which adolescents' participation in a youth development program may be linked to the participants' post-secondary education and career aspirations. This study indicated that the Virginia $4-\mathrm{H}$ youth development program had positive impact on youth's career decisions in relation to specific years of program involvement, race/ethnicity, and specific curricular participation. 
Early exposure to higher education is beneficial to students. For many of the youth attending the career/college fair, it was helpful to discuss attending college with various college representatives. Representatives from the college departments enlightened the students about careers that should be considered. Youth development specialists might consider taking young people to visit various colleges. Specialists might also consider inviting representatives from college departments to engage in activities with the youth in their programs.

Individuals who work with youth development programs might consider exposing youth to various careers through projects. Youth could learn about various careers, which would assist them in career decision making. It would be beneficial for the projects to have a set of standardized goals and learning outcomes. This would make the programs' impact easier to assess.

Youth development programs assist young people in making decisions about their future. Whether the programs focus on careers or postsecondary education, these programs are vital to helping young people understand their interests and values.

\section{References}

Adams, J.R., Benshoff, J.M., \& Harrington, S.Y. (2007). An examination of referrals to the school counselor by race, gender, and family structure. Professional School Counseling, 10, 389-398.

Ali, S.R., \& Saunders, J.L. (2006). College expectations of rural Appalachian youth: An exploration of social cognitive career theory factors. The Career Development Quarterly, $55,38-51$.

Anderson, S., \& Brown, C. (1997). Self-efficacy as a determinant of career maturity in urban and rural high school seniors. Journal of Career Assessment, 3, 305-315.

Arnold, M.E. (2003). Using multi-site methodology to evaluate 4-H youth leadership retreats. Journal of Extension, 41(6). Retrieved from: www.joe.org/joe/2003december/rb1.php.

Carter, L., Thompson, G.L., \& Warren, S. (2004). It's not my fault: Predicting high school teachers who blame parents and students for students' low achievement. The High School Journal, 87, 5-14.

Childs, G., \& McKay, M. (2001). Boys starting school disadvantaged: Implications from teachers' ratings of behaviour and achievement in the first two years. British Journal of Educational Psychology, 71, (2), June 2001, 303-314.

Cicourel, A.V., \& Kitsuse, J.I. (1963). The use of official statistics. Social Problems, 11, 131-139.

Duffy, R.D., \& Blustein, D.L. (2005). The relationship between spirituality, religiousness, and career adaptability. Journal of Vocational Behavior, 67, 429-430. 
Garst, B.A., Hunnings, J.R., Jamison, K., Hairston, J., Meadows, R.R., \& Herdsman, W.R. (2006). Exploring the adolescent life skill outcomes of State 4-H Congress participation and the different outcomes of gender and race groups. Journal of Extension, 44(6). Retrieved from: www.joe.org/joe/2006december/rb2.php.

Gottfredson, L.S. (1981). Circumscription and compromise: A developmental theory of occupational aspirations. Journal of Counseling Psychology, 28, 545-579.

Hendricks, P.A. (1996). Developing youth curriculum using the Targeting Life Skills model: Incorporating developmentally appropriate learning opportunities to assess impact of life skill development. Ames, IA: Iowa State University Extension.

Holland, J.L. (1959). A theory of vocational choice. Journal of Counseling Psychology, 6, 3545.

Holland, J.L. (1985). Vocational preference inventory professional manual. Odessa. FL: Psychological Assessment Resources.

Holland, J.L. (1997). Making vocational choices: A theory of vocational personalities and work environments (3rd. Ed.). Lutz, FL: Psychological Assessment Resources, Inc.

Hummel, T.J. \& Lichtenberg, J.W. (2001). Predicting Categories of Improvement Among Counseling Center Clients. Paper presented at the annual meeting of the American Educational Research Association, Seattle, WA.

Jackson, M.A., Kacanski, J.M., Rust, J.P., \& Beck, S.E. (2006). Constructively challenging diverse inner-city youth's beliefs about educational and career barriers and supports. Journal of Career Development, 32, 203-218.

Jackson, M.A., \& Nutini, C.D. (2002). Hidden resources and barriers in career learning assessment with adolescents vulnerable to discrimination. Career Development Quarterly, 51 (1), 56-77.

Kress, C. (2004). The essential elements of 4-H Youth Development: Distillation to four elements. Washington, DC: CSREES/USDA.

Leedy, M.G., LaLonde, D., \& Runk, K. (2003). Gender equity in mathematics: Beliefs of students, parents, and teachers. School Science and Mathematics, 103(6), 285.

Lent, R.W., Brown, S.D., \& Hackett, G. (1994). Toward a unifying social cognitive theory of career and academic interest, choice, and performance. Journal of Vocational Behavior, 45, 79122.

Meinster, M.O., \& Rose, K.C. (2001). Longitudinal influences of educational aspirations and romantic relationships on adolescent women's vocational interests. Journal of Vocational Behavior, 58, 313-327.

Michigan State University Cooperative Extension. Career fair interviewing (bulletin). (2009). Retrieved from: http://web1.msue.msu.edu/4h/careers/documents/CF-InterviewingMoreActivity.pdf. 
Mitchell, L.K., \& Krumboltz, J.D. (1996). Social learning approach to career decision making: Krumboltz's theory. In Brown, D, Brooks, L., \& Associates. Career choice and development: Applying contemporary theories to practice. (2nd ed). San Francisco: Jossey-Bass.

Moore, D.S., \& McCabe, G.P. (1989). Introduction to the practice of statistics. New York: W.H. Freeman and Company.

National Institute of Food and Agriculture (2009). Retrieved from: http://www.csrees.usda.gov/

Norusis, M.J. (2008). SPSS 16.0 Guide to Data Analysis, Prentice Hall, New Jersey, USA.

Patton, W. \& McMahon, M. (1999). Career development systems theory: A new relationship. Pacific Grove, CA: Brooks/Cole.

Rollins II, C. (2003). High School Guidance Counselor Ratings of Success for Post Secondary Options: A Study of Socioeconomic, Racial and Gender Bias. Unpublished doctoral dissertation, University of Kentucky.

Root, M.P.P. (1996a). The multiracial experience: Racial borders as a significant frontier in race relations. In Root, 1996b, pp. 23-28.

Root, M.P.P. (Ed.). (1996b). The multiracial experience: Racial borders as the new frontier. Thousand Oaks, CA: Sage.

Salomone, P. (1996). Tracing Super's theory of vocational development: a 40-year retrospective. Journal of Career Development, 22, 167-184.

Super, D.E. (1954). Career patterns as a basis for vocational counseling. Journal of Counseling Psychology, 1, 12-20.

Thomas, E.H., \& Galambos, N. (2002). What Satisfies Students? Mining Student-Opinion Data with Regression and Decision-Tree Analysis. Stony Brook, New York: Stony Brook University.

Tomini, B.A., \& Page, S. (1992). Vocational bias and gender: Evaluations of high school counselors by Canadian university undergraduates. Canadian Journal of Counseling, 26 (2), 100-106.

Tournaki, N. (2003). Effect of student characteristics on teachers' predictions of student success. Journal of Educational Research, 96, 1-12.

Turner, S., \& Lapan, R.T. (2002). Career self-efficacy and perceptions of parent support in adolescent career development. Career Development Quarterly, 51 (1), 44-55.

Verhoeve, D. (2003). A look at Donald Super's stages of career development in the 21st century. Contactpoint. Retrieved from

http://www.contactpoint.ca/index.php?option=com content\&view=article\&id=354:a-look-atdonald-supers-stages-of-career-development-in-the-21st-century\&catid=58:spring$\underline{2003 \& \text { Itemid }=37}$.

Virginia Cooperative Extension. (n.d.). State 4-H Congress. Retrieved from: http://www.4-h.ext.vt.edu/programs/congress/index.html 
Williams, B. \& Taylor, T. (2008). Career Decision Survey, unpublished survey, Virginia Cooperative Extension, Blacksburg, VA.

(C) Copyright of Journal of Youth Development Bridging Research and Practice. Content may not be copied or emailed to multiple sites or posted to a listserv without copyright holder's express written permission. However, users may print, download or email articles for individual use. 